\title{
All the World's a Stage - the Information Practices and Sense-Making of Theatre Professionals
}

\author{
Michael R. Olsson \\ Dr. Michael R. Olsson, Senior Lecturer, Journalism, \\ Information and Media Studies Group, Faculty of \\ Arts and Social Sciences, University of Technology, \\ Sydney, Australia. \\ Email: Michael.Olsson@uts.edu.au
}

This paper is based on a presentation at the international conference ' $\mathrm{i}^{3}$ : Information: Interactions and Impact', organized by the Robert Gordon University's Department of Information Management, and held in Aberdeen, Scotland, 22-25 June 2009.

\begin{abstract}
This paper reports on the findings of a study examining how theatre professionals (actors, directors and others) make sense of the works of a culturally iconic author (William Shakespeare). The study aims to address critique of prevailing approaches' excessive focus on active information seeking and searching (Julien 1999; Wilson 2000) by developing a more holistic approach, one which acknowledges the complexity of sense-making as more than the problemsolving behaviour of individuals - as an embodied, social process, involving emotion as well as rationality. In doing so it draws on theoretical approaches from a range of different disciplines and traditions, including Dervin's Sense-Making, Foucault's discourse analysis and Derrida's deconstructionism. The findings of the study are based on interviews with 35 theatre professionals in Canada, Finland and the UK.
\end{abstract}

All the world's a stage,

And all the men and women merely players:

They have their exits and their entrances;

And one man in his time plays many parts,

(As You Like It)

This paper reports on the findings of a study examining how theatre professionals (actors, directors and others) make sense of the works of a culturally iconic author (William Shakespeare). The research builds on the theoretical and methodological approaches developed during my doctoral research (Olsson 2003). The study aims to address critique of prevailing approaches' excessive focus on active information seeking and searching (Julien 1999; Wilson 2000) by developing a more holistic approach, one which acknowledges the complexity of sensemaking as more than the problem-solving behaviour of individuals - as an embodied social process, involving emotion as well as rationality.

In doing so, it draws not only on Dervin's SenseMaking but also on a number of concepts from the discourse analytic tradition. These include 'Death of the Author' (Foucault 1972, 1977, 1980; Rabinow 1984; Barthes 1988) - the notion that meaning is not determined by authors but constructed through discourse - and the embodiment of knowledge (Coupland and Gwyn 2003) - the idea that people's engagement with information involves more than just cognitive processing. It therefore aims to further our understanding of a variety of phenomena relating to knowledge sharing practices, collective sense-making and the discursive construction of knowledge.

\section{Why Shakespeare?}

He was not of an age, but for all time!

(Jonson, First Folio)

Shakespeare in performance was chosen as the focal author of the research for two key reasons. Firstly, despite Shakespeare's acknowledged role as an important figure in the cultural heritage of the Englishspeaking world, it is a context that has been almost entirely ignored by information researchers, Secondly, I believed that it would be a fruitful context in which to explore sense-making in a more holistic way than has generally been the case in information research - to begin to understand sense-making not merely as logical problem-solving but as:

... embodied in materiality and soaring across time-space ... a body-mind-heart-spirit living in time-space, moving from a past, in a present, to a 
future, anchored in material conditions; yet at the same time with an assumed capacity to sensemake abstractions, dreams, memories, plans, ambitions, fantasies, stories pretences that can both transcend time space and last beyond specific moments of time space. (Dervin 1999, 730)

In doing so, the study's findings have important implications for understanding not only the sensemaking processes of theatre professionals but everyone - from athletes to zoologists.

Despite the acknowledged importance of theatre and Shakespeare in particular - in the Western world, and despite being the object of research in a wide variety of other disciplines, there has been very little empirical research examining the information behaviour of theatre professionals, indeed of artistic communities in general. Much of what research there has been (e.g. Pilch 1987; Cobbledick 1996; Atkins 2001) has focused almost exclusively on their need for and/or use of formal information sources and services, such as libraries, databases etc. A notable exception to this is Davies (2007) which examined the role of a text (prompt book) as a temporal boundary object - "abstract or concrete objects which both inhabit several intersecting social worlds and satisfy the informational requirements of each of them" (Davies and McKenzie 2004). This study suggested that texts play a vital role in the negotiation and coordination of the disparate understandings and expertises of members of a theatre company. Examining this question would also play an important role in the present study.

Shakespeare is a major cultural icon. His work has been the object of centuries of literary and academic attention in fields as diverse as literary criticism, history, philosophy, cultural anthropology, sociology, cultural studies and psychology, as well as performance studies. During this time, Shakespeare and his work have been constructed in a myriad of different ways by a plethora of scholarly groups drawing on an vast array of different theoretical discourses for example, semiotics, cultural materialism, feminism, Foucauldian discourse analysis, new historicism and Derridan deconstructionism are all employed by writers contributing to a single anthology on Shakespeare in performance (Bulman 1996). The history of theatrical productions of his work is equally rich and diverse, with major professional productions of Shakespeare in Australia in recent years, for example, drawing inspiration from sources and issues as diverse as Freudian psychology, Japanese kabuki and the indigenous land-rights debate (Golder and Madelaine 2001). Productions of Shakespeare are a lens through which audiences can see reflected society's constantly changing attitudes to love, war, family, jealousy, the supernatural, gender etc - what it means to be human. As a consequence, examining how theatre professionals make sense of Shakespeare in order to turn centuries-old words into a living production for a contemporary audience, was the perfect site to study Barthes and Foucault's concept of 'death of the author' - the idea that meaning is not determined by authors but constructed by readers (and in this case, audiences). The study has sought to explore the interplay of how these diverse constructions - as well as the sometimes convergent, sometimes divergent interests of actors, directors, designers and technicians - interact in the cooperative environment of producing a theatrical production.

\section{Prevailing approaches}

And do as adversaries do in law, strive mightily, but eat and drink as friends.

(The Taming of the Shrew)

The second major reason for undertaking the study was the opportunity it afforded to focus on aspects of information behaviour that have been largely neglected in prevailing approaches to research in the field. The historical antecedents of information behaviour research lie in library and information system evaluation (Wilson 2000) and it is therefore important, as Julien (1999) has pointed out, for us to consider the extent to which prevailing 'user-centred' approaches to information research and models of information seeking are based on an implicitly systems-centric perspective. If one of the cornerstones of Dervin and Nilan's (1986) analysis of traditional, systems-centred information research was a critique of its narrow, focus on systems use, then perhaps it is time for us to ask whether the usercentred paradigm has gone far enough. Indeed, as Julien (1999) also pointed out, the continued use of the term 'user' is significant in this context: it carries with it the implication of a silent 'system'. This implicit systems-focus has influenced the development of mainstream contemporary information behaviour 
research in a number of ways. These include: a theoretical and empirical focus on purposive information seeking and searching; a focus on information need as the primary instigator of information behaviour; the prevalence of an individually-focussed, problem-solving construction of information behaviour; and the pre-eminence of cognitivist theoretical and methodological approaches.

Wilson has pointed out that information search behaviour is only one aspect of information seeking behaviour, which is itself only one aspect of information behaviour. Yet, as he also noted, "Models of information behaviour ... appear to be fewer than those devoted to information-seeking behaviour or information searching" (2000, 49). This apparent discrepancy is clearly one example of the ways in which the socio-historical/discursive context of information behaviour research has influenced the research interests and practices of researchers in the field. For while information seeking and searching behaviour may only comprise a small percentage of the average person's information behaviour, it remains the aspect that is perceived as being of greatest interest to the designers and managers of information systems and services. Such a narrow focus, however, casts into question the field's claims to have moved beyond systems evaluation to the development of so-called general models of information behaviour.

The focus on purposive information seeking may be why, since at least the early 1980s, theories and models of information seeking/behaviour have information need as the central focus of theoretical attention, regarding it as the instigator of information behaviour. Belkin (1990), for example, argued that information seeking behaviour is driven by a person's recognition of an Anomalous State of Knowledge (ASK) - that their existing knowledge structures are no longer adequate to resolve their current problemstate. Other influential models of information behaviour to position information need and uncertainty as central concepts include: Krikelas (1983), Ellis (1993), Kuhlthau (1993) and, Wilson (1997). All these models follow a common pattern: a recognised information need/gap/anomalous state of knowledge is seen as instigating active information seeking; this active seeking continues until the need is met/ gap is filled or the seeker abandons the search.

Frohmann (1992), Talja (1997) and Julien (1999) have all critiqued this narrow focus on information need. They pointed out that this has led to a construction of the user in which "[t]heir ignorance ... rather than their knowledge" (Frohmann 1992, 379) is their defining characteristic. Similarly Julien argued that prevailing approaches "conceive of users of information systems as 'children' or 'patients' whose symptoms require diagnosis" (Julien 1999, 586). Talja argued that information users might, with at least equal validity, be defined not by their lack of knowledge in relation to a given problem situation - as "uncertain people who need help" but rather as "knowing subjects, as cultural experts" (Talja 1997, 77). The present study has sought to acknowledge and gain an understanding of participants' cultural expertise, to recognise them as:

... an expert in her world (e.g. in her body, her work, her life) ... Sense-Making assumes the actor as theorist of her world, with hunches, hypotheses, and generalizations about how things connect to things and how power flows. (Dervin 1999, 740)

The field's focus on the purposive information seeking of individuals has led to an essentially atomistic approach to constructing information behaviour. A number of factors are likely to have contributed to this focus, including the growing influence of both marketing discourses in the information professions (indeed Western society in general), and cognitivist theories in information research. However, perhaps one reason for the success of such 'fairy-tale' models (like fairy tales, they have a clearly defined beginning, middle and an end) is that they echo the pattern of many information professionals' interactions with their client, such as a reference interview or a database search i.e. beginning with defining a query, proceeding through purposive searching and concluding with the client supplied with 'information'. Yet the question we need to ask ourselves is: while such models might effectively represent the information professionals' view, are they equally effective at representing other people's sense-making processes? Or do they actually represent a tacitly systems-centred orientation? Are they compatible with the field's stated desire to develop a holistic understanding of people's relationship with information?

My own previous research (Olsson 2003, 2005, 2007) examining information researchers' con- 
structions of a prominent author (Brenda Dervin) produced findings in marked contrast to these prevailing atomistic models. Participants' accounts emphasised the ongoing nature of their sense-making processes - a journey lasting many years - decades, in some cases - with each 'step' influencing their subsequent understanding and behaviour. They emphasised the importance of long term relationships with people and with texts - and demonstrated that these relationships were frequently inter-related, explicitly linking their engagements with texts to their interactions with other people. The present study would aim to see if the same were true in the very different context of the world of theatre professionals. Would the transitory nature of theatre, for example, lead to a greater focus on the present? To what extent would participants' sense-making be influenced by an on-going sense of Shakespeare, as opposed to, in the words of the great director Peter Hall, considering the play "as if that morning it had dropped through the letterbox onto the front doormat" (Berry 1977, 57).

Another major attraction of studying theatre professionals was the opportunity it afforded to explore the role of affect in their sense-making processes. Julien has commented that information researchers have tended to regard affective factors as "at best only an annoying interference with effective application of cognitive skills to information retrieval but ..., at worst, are the primary barriers to information retrieval" (1999, 586). Certainly, it is notable that prominent attempts to incorporate affect into theories of information behaviour, such as Kuhlthau (1993), have focussed on negative emotions such as stress and uncertainty.

By contrast, my own previous research (Olsson 2003, 2007) showed that, even in the context of academic research, affect played an important and largely positive role in participants' sense-making. Participants' friendships, for example, with their colleagues and, in many cases, with the author herself, meant that they were both better able to understand and more likely to trust meanings conveyed to them. Successful research collaborations were more likely to occur between researchers who liked one another!

More recent times have seen a growing interest in the role of emotion on information behaviour, including an edited book on the subject (Nahl and Bilal 2007). However, much of this research is individually focussed and essentialist in its construction of emo- tion - grounded in a scientific discourse which sees affect as fundamentally acultural. The present study adopts a different approach, seeking to understand the social role of emotion. The study's theatrical context offered a unique opportunity here: whilst most Western professional and academic discourses operate in a post-Enlightenment paradigm which values logic and rationality, the theatre is a context where 'emotional truth' is recognised as an important and legitimate part of the creative process.

\section{An alternative approach - a new discourse?}

\section{O Brave New World \\ (The Tempest)}

The aim of the present study was therefore to develop an approach to information research which addressed critique of prevailing approaches to information behaviour research. In doing so, it draws on a range of different theoretical and methodological approaches drawn from a range of disciplines.

Savolainen (2007) has outlined the emergence of a new "umbrella discourse" in information studies 'information practice' - which has emerged in the first decade of the twenty-first century as a critical alternative to the 'information behaviour' discourse which characterises prevailing approaches. Savolainen follows Talja in suggesting that the key characteristic of this new discourse is that it represents "a more sociologically and contextually oriented line of research" which:

... shifts the focus away from the behavior, action, motives and skills of monological individuals. Instead the main attention is directed to them as members of various groups and communities that constitute the context of their mundane activities. (Savolainen 2007, 120)

My own research as connected to this emerging discourse: it is grounded in an understanding that participants' sense-making/s are an essentially social process and recognises that they need to develop their understanding in the context of a collaborative creative process. Both meta-theoretically and methodologically, it is a hybrid, drawing not only on existing information behaviour research but on a range of different ideas and approaches from a variety of disciplines in order to develop an alternative ap- 
proach - a different lens with which to explore the relationship between people, information and their social context. It been strongly influenced by theories and techniques derived from the work of poststructuralist theorists such as Michel Foucault (1972, 1977, 1980; Rabinow 1984), and Jacques Derrida (1992, 1997), as well as the more recent developments of Dervin's Sense-Making (1999). Foucault's theories on the discursive construction of power/ knowledge have been used by a number of writers in an LIS context (e.g. Frohmann 1992; Talja 1997; Olsson 1999, 2005, 2009) to problematise and challenge some of the key assumptions that underpin existing approaches to information research, especially those associated with the influential cognitivist school.

Foucault argued that knowledge is not objective to be measured in terms of its supposed correspondence to an external reality - but rather an intersubjective social construct, the product of the shared beliefs and interpretive practices (what Foucault called the discursive rules) shared by a particular community or communities at a particular point in space and time. "For Foucault, there is no external position of certainty, no universal understanding that is beyond history and society" (Rabinow 1984, 4). Derrida's deconstructionist approach is grounded in a parallel worldview. Derrida argues that since all meaning is contextual and based on difference, any philosophical or social theory that claims to uncover a 'fundamental' truth is inherently flawed. His deconstructionist approach is thus a "method for revealing the radical contextuality of all systems of thought" (Dickens and Fontana 1994).

One important conceptual starting point for my research has been Barthes (1988) and Foucault's (1980) notion of 'Death of the Author' - that the meaning of a text is not prescribed by authors but constructed by audiences. Equally significant has been Foucault's notion of pouvoir/savoir - that the discursive practices of associated with the "Battle for Truth" are both grounded in and the producers of power relations. The present study can be seen as a micro-sociological exploration of these concepts in the context of a collective artistic endeavour. Studies of Shakespeare in performance talk frequently of the advent of a 'Post-Colonial' Shakespeare, 'Australian' Shakespeare, 'Canadian' Shakespeare, 'AfroCaribbean' Shakespeare etc. (Golder and Madelaine 2001) - that particular national and cultural com- munities are increasingly finding alternative locallyappropriate ways to construct the Bard. Through working with participants from different countries associated with different theatre companies, the study aimed to explore how their different social contexts shaped their sense-making processes.

\section{Methodology}

Though this be madness, yet there is method in 't. (Hamlet)

The findings of the study are based on interviews with 35 theatre professionals in Canada, Finland and the UK, including 14 from the Stratford Shakespeare Festival of Canada, North America's largest and most prestigious classical repertory theatre, and 12 from Shakespeare's Globe in London. Other participants include actors, writers and directors associated with the Royal Shakespeare Company, the National Theatre and the Central School of Speech and Drama in the UK and the Tampereen Työväen Teatteri in Finland. Participants included actors, directors, set and costume designers, voice coaches, dramaturges and writers, with some participant having experience in more than one such role.

The interview guide incorporated aspects of the 'Life-Line' techniques developed by Dervin and her collaborators (Dervin and Frenette 2001) but was also influenced by the less structured, more conversational approach advocated by Seidman (1991) as a means of empowering the participants and reducing the influence of my own preconceptions. Participants were asked to describe the events and relationships that have shaped their relationship with Shakespeare and his work, as well as Shakespeare's 'place' - in their own work, in the academy, the theatre world, and in contemporary society.

One major challenge of the present study was that many of the participants, especially actors and directors, were very used to being interviewed - talking to the press being part of their job. This had both positive and negative aspects. On the one hand, these participants were confident and comfortable in talking about themselves, with a ready supply of amusing anecdotes to hand. However, this meant that it was important to develop strategies that probed below the polished surface of these oft-told stories, to have participants reflect on what events and relationships were important - and why. 
Overall, the research was successful in achieving this - even the briefest interview (cut short by the participant's time constraints) lasted just over an hour, with many running more than two or even three hours. A number of participants commented that they found the interviews a revealing process, offering them an opportunity to reflect on their professional life in a way they had not done before. The interviews were digitally audio-recorded and professionally transcribed prior to analysis.

The study used an inductive approach to analysis, derived in part from the 'constant comparison' approach pioneered by Glaser and Strauss (1967). Although inductive, the analysis was clearly informed by the researcher's engagement with the theoretical literatures and traditions, as outlined above. This process included both a detailed micro-analysis of the interview transcripts, aided by the use of NVIVO software, as well as the broader thematic writing techniques advocated by Glaser and Strauss (1967) to explore emergent trends, concepts and theories. Participants played an active role in the analysis process through follow-up interviews, email correspondence, etc.

\section{Findings}

\section{Social sense-making}

When shall we three meet again in thunder, lightning, or in rain?

(Macbeth)

As in my previous research (Olsson 2005, 2007), a strong feature of the findings is the relative lack of importance participants attached to purposive information seeking, especially of formal information sources or systems, with only a minority (6 - two dramaturges, one writer, one voice coach and two actors) reporting it as a significant part of their sensemaking. Indeed, many participants regarded most of the published Shakespearean literature - whether literary criticism or performance studies as not useful:

When I read most of what's written, I just roll my eyes! I find myself thinking "Have they ever seen the play?" They're off in their own world and I don't think it has much to do with what I do ... (Hero, Actor)
Well, let's face it, most of them [performance studies academics] think they know better than us - secretly think they could do better than us - but they can't! If they could they'd be doing it ... (Mercutio, Director)

Indeed, this suspicion of the academy was a strong discourse in many participants' accounts: it was characterised not only by a belief that academic writing on the subject was obscure and irrelevant but a suspicion that academics look down on theatre professionals. One interesting consequence of this was that many participants were much happier talking to me once they ascertained that I wasn't 'one of them' - that I was not a Shakespeare or performance studies researcher. This discourse was closely related to another (discussed below): that theatre professionals are the true custodians of Shakespeare.

Instead of searching for information, the events that participants described as having the greatest influence on their understanding of Shakespeare were 'social' interactions: informal conversations with their colleagues or mentors, interactions at rehearsals - social activities associated with their role/s as actors, directors etc.:

You learn the most just being in the rehearsal room with other actors ... not that you try and copy them but just seeing how they work, what the process is ... when I understudied for Julia, it was like following her tracks in the snow ... you know, I could see where I should put my feet ... (Portia, actor)

Really, it's only when you talk to the director, get a sense of what his vision for the production is, that I can really start to think about my designs. Then I can start coming up with ideas ... see what he thinks ... (Sebastian, designer)

Participants in the study frequently explicitly linked their engagements with texts to their interactions with other people:

Obviously I'd read the play, done background research, seen it on stage but it wasn't 'til I got into the rehearsal room, starting working with Iago [the director] and the other actors that I really started to feel I understood it ... that's usually how it goes. (Timon, actor) 
When I start out on a new production, I work a lot with our dramaturge. We discuss the text ... I rely on her expertise. And then very often, she'll go out and do some research, based on what we've talked about and come back to me. (Iago, director)

In two companies, the dramaturge was seen, both by him/herself and by other members of the company, as having an 'information professional' role seeking out useful literature on behalf of actors and directors:

Part of what I do is find out what will help them. One actor might want to know all about the actual kings and queens of England, another might want to know about how such and such a metaphor comes from hawking, so they want to know about that. Others want to know about what people thought about ghosts at the time ... (Andromache, dramaturge)

We have a wonderful dramaturge [Andromache] and she's always coming in with a wonderful range of books and articles, which she leaves in the rehearsal room and that you can take away with you ... (Cressida, Actor)

It was clear from participants' accounts that their sense-making was seldom a linear process:

... it's hard to describe, you're reading, you're talking to the director, working with the other actors, doing sessions with the voice coaches, the movement coaches - and all of this is part of your process as you're working out who your character is. (Portia, actor)

\section{Ongoing relationships}

Sir, my good friend; I'll change that name with you (Hamlet)

Participants frequently described the significant influences on their constructions in terms of long-term relationships - with other people and with the written work of authors. Long term relationships with colleagues were highly valued and seen as greatly facilitating information exchange:
I've worked with Iago before ... I love working with him... You develop a sense of what he wants .... you don't have the worry "Is this what he means?" (Timon, actor)

Unsurprisingly, long term relationships were particularly strong in repertory companies and/or companies like Stratford, where it is common for many theatre professionals to have been associated with the company for many seasons. The corollary of this, however, may be that it may be more difficult for 'outsiders' to find a place in these tight-knit worlds:

I was watching 'Othello' and I realised that everyone except Othello had come through the Academy ... worked together. Then again, perhaps that works for him - Othello is the outsider in the play ... (Portia, actor)

I think there is a 'Stratford way' of doing things and sometimes when a new director comes in and wants to do something different, there can be some resistance. (Sebastian, designer)

Rather than a series of isolated encounters with information sources, participants spoke of the ongoing nature of their relationships. Each individual encounter (whether with a person or a text) built on the participant's previous experience, enriching their constructions of both Shakespeare and their informants.

\section{Constructing Shakespeare}

Why, man, he doth bestride the narrow world

Like a Colossus ...

(Julius Caesar)

Of course, for all participants the longest and most significant relationship was with Shakespeare:

I've been performing Shakespeare for more than four decades now. On the one hand, he's like an old friend but I'm always finding something new. You bring your experience, your craft, your sense of what Shakespeare is, to each production. It forms your approach - but then you always find something unexpected - a new insight, something unexpected ... amazing. (Rosencrantz, actor) 
All of the participants reported being introduced to Shakespeare in childhood. Interestingly, while almost all participants described studying Shakespeare at school, for 34 of the 35 participants, it was seeing his work performed, either on stage or in the cinema, that they regarded as being the crucial starting point for their professional engagement with his work:

I came here ... as a schoolchild .... A while ago I was standing on the main stage here with Margaret and we were wondering how many of us had had that experience ... (Andromache, dramaturge)

My mother took me to see 'Romeo and Juliet' when I was about seven. I felt so smart! I was "Of course I understand it, Mother!" ... I knew then that's what I wanted to do ... (Imogen, actor and director)

A 'Shakespeare as Genius' discourse was a notable feature of all participants' accounts:

They are so well written ... Shakespeare's language is like no one else's (Rosencrantz, actor)

I just think his characters are so well-rounded .... The stories still speak to us all these centuries later ... (Mistress Overdone, actor)

Perhaps unsurprisingly, this discourse was particularly strong at Stratford and the Globe, where Shakespeare is central to the company's identity but was present, albeit in somewhat muted form, even in the accounts of the Finnish participants:

For us perhaps, he is not so central, but he is like the Greeks, the Russians - Chekhov - or Moliere

$\ldots$ he is a major writer for western civilization. (Nerissa, dramaturge)

Yet all participants' relationship with Shakespeare were grounded in two essentially contradictory discourses: one of which, allied to the 'Shakespeare as Genius' discourse, valued authenticity, saw the theatre professionals as the true custodians of Shakespeare's work:

You know, I don't think you can really understand Shakespeare, until you perform it ... the plays were written to be performed, not read. (Ned Poins, actor)

It's kind of amazing to think of yourself as being part of a tradition that goes back through the centuries ... to Shakespeare and the Globe. And I think you feel a responsibility to carry on that tradition, to honour it. (Seyton, actor)

This discourse leads theatre professionals to read Shakespeare in a particular way - to seek out its 'true' meaning, clues to authorial intent. This is a discourse that seeks to deny that meaning is something created by the reader, even as they are engaged in exactly this process. Adverse comments about post-modern academic approaches to studying Shakespeare, evident in six participants' accounts, may be partially attributable to this discourse.

\section{Shakespeare as director}

Speak the speech, I pray you, as I pronounced it to you, trippingly on the tongue

(Hamlet)

A highly sophisticated set of practices for reading Shakespeare, have developed among classically trained actors, directly related to this 'authenticity' discourse:

Shakespeare actually tells you how to speak the lines! If you look at the blank verse, it shows you when to pause, what to give emphasis to ... $\mathrm{He}$ does the work for you ... (Rosencrantz, actor)

This 'Shakespeare as Director' discourse, essentially argues that instructions on how to perform Shakespeare are integral to the structure of the text the blank verse, the use of punctuation in the First Folio etc. Seven participants, all classically trained actors, had a particularly sophisticated engagement with this discursive practice.

At the same time, all participants' accounts also draw on another, quite contradictory discourse, one which values creativity - bringing something "new and fresh" to a production:

We wanted to do something very new with this production - very political ... (Puck, actor) 
I don't like to see other productions or watch films because I want to come up with my own interpretation, not just copy what they've done. (Viola, actor)

You need to find new settings, new approaches to the design ... get away from 'pumpkin pants' Shakespeare! (Sebastian, designer)

Allied to this discourse, is a concern with making the plays relevant to a contemporary, local audience:

One of the best productions I've seen was a Romeo and Juliet from Quebec... the Capulets were Francophone and the Montagues were Anglophone ... (Rosalind, voice coach)

An actor once said to me "How do I be a Canadian Prince of Denmark?" And really that's what it's all about ... making a modern audience believe he IS Hamlet !...how do you get across the idea of what royalty means to a modern audience? (Rosalind, voice coach)

These two discourses are frequently in opposition in participants' accounts, with the one being used to critique the other:

You know, in many ways I envy my overseas colleagues who get to work with Shakespeare in translation, because they don't have to worry about the problems of archaic language that audiences can't understand ... but we're all "You can't change it, it's SHAKESPEARE!" (Andromache, dramaturge)

Well we have a director now, he's very focussed on the look of the thing, making a big spectacle, but to me that's going against what Shakespeare is about - the characters, the language ... (Antony, Actor)

Clearly, any production of Shakespeare is influenced by both these discourses, as the theatre professionals involved, both individually and collectively, seek to reconcile the precepts of these two powerful, yet contradictory discourses. It may well be that this discursive contradiction actually enhances and energises the creative process.

\section{Affective discourse}

I will wear him

in my heart's core, ay, in my heart of heart, (Hamlet)

In contrast to prevailing approaches, which either ignore affect or construct it as a barrier to effective information seeking, in the current study, participants tended to describe emotion as a positive part of their sense-making. Theatre professionals in general, and actors in particular, demonstrated a strong awareness of the importance of emotion for their sense-making:

As an actor, you need to do more than understand the play in an academic way... you need that emotional connection to the character and to the story. I need to FEEL it! (Imogen, Actor)

Furthermore, affective sense-making - 'emotional truth' - played an acknowledged role in theatre professionals' interactions with one another, especially amongst actors and directors:

Some directors are more interested in the spectacle ... treat you like a puppet - "Go down stage and stop here." But the really good directors, what I call 'actor's directors', who really help you find the character, talk a lot about what you character should be feeling at that point in the play. (Antony, Actor)

I was having trouble with one scene, so I went and talked to another member of the company, who I knew had played the part before ... I asked him "What should I be feeling at this point?" (Timon, Actor)

Thus, amongst theatre professionals, 'emotional truth' is both the subject and the generator of discourse, a socially-validated practice and an acknowledged source of authority. This may be a contributing factor in many participants' tendency to regard academic writing on Shakespeare, with its conspicuous lack of an affective component, as "dry", "sucking the life out of it."

Theatre professionals' acknowledgement of the importance of affect for their sense-making, also meant that they were attuned to recognising its significance, in other contexts: 
I went to the university library with my husband's card and got out everything they had on As You Like It. And I was reading one ... it made me so angry I threw it across the room! And then I went "Wait - anger's good. It means you must know something. Why does it make you angry?" And that was a really big breakthrough for me. (Portia, actor)

This particularly striking example of an apparently 'negative' emotion playing a positive role in a participants' sense-making also suggests that we should question the utility of viewing affect in this way. Affect, it seems clear, plays a much more complex role in people's individual and collective sense-making than most information researchers have hitherto acknowledged.

\section{Embodiment}

... can this cockpit hold

The vasty fields of France? or may we cram

Within this wooden $\mathrm{O}$ the very casques

That did affright the air at Agincourt?

(Henry V)

The influence of cognitivist approaches modelled on Brookes' (1980) fundamental equation has led information researchers to conceive of information as anything which modifies an individual's knowledge structures. Yet the findings of this study suggest that such a "mentalist" approach (Frohmann, 1992) is too limited to capture the complexity of participants' sense-making. Discourse analytic approaches, which their emphasis on knowledge as a social construct embedded in power relations, go some way in addressing this limitation, yet it may be that their emphasis on language may also leave important aspects of sense-making unconsidered.

For theatre professionals, understanding Shakespeare involved much more than a cerebral process: their professional lives are based on the ability to embody their knowledge: they need to manifest their understanding in the physical world as physical actions in physical space. Designers need to do this through set and costume designs, directors through 'blocking' the movements of their actors, constructing the action to suit the confines and challenges of a particular physical space:
As I'm going through the text, I need to constantly think about how I'm going to make this work ... especially in this theatre with its long thrust stage and audience on three sides ... sometimes an actor is going to have to be acting with his back. (Iago, director)

They therefore read the text of Shakespeare's plays through the lens of their material concerns. At the same time, their physical environment can shape their understanding of the text:

We've learned so much working here at the Globe. You realise that Shakespeare was actually writing for this stage. For example, I've found that many of the big speeches, the soliloquies, give actors exactly enough time to get from the balcony above to the main stage. (Horatio, actor and voice coach)

Wilson (1997) has highlighted that information researchers' focus on information seeking has led them to neglect information use. However, while 'information use' implies an interaction between two discrete entities (person and information), 'embodiment', in my view, provides a richer understanding of the process by which new sense is incorporated into the participants' practices.

\section{Embodied sense-making}

Then imitate the action of the tiger:

Stiffen the sinews, summon up the blood.

(Henry V)

For actors, embodiment is a much more literal process: they need to physically become their character (at least for a few hours' traffic upon the stage):

I need to find the character's voice ... the way they move. That's where the voice and movement coaches can be so helpful. (Portia, actor)

A bunch of the young actors, we formed 'Medieval Fight Club' ... we'd get in one of the big rehearsal rooms and really go at it! Because it's no good coming across as a bunch of actors playing about with prop swords, you need to look like you know what you're doing. ... at the same time, it gave me a real insight into the character ... as a warrior. (Timon, actor) 
Actors accounts make it very clear that for them to make sense of a character involves not only intellectual and affective elements but also physical ones: how the character walks, talks, laughs etc. - it is this embodied knowledge that is the basis of their performance.

Embodiment is not a concept that information behaviour researchers have hitherto engaged with, and work focussing on it is also rare in the other social sciences (Coupland and Gwyn 2003). It is, however, a concept that might usefully be applied to the sense-making of many other groups and professions, and is therefore an area that warrants significant further research.

\section{Conclusion}

At least we'll die with harness on our back. (Macbeth)

In bringing together theoretical and methodological approaches from a range of different disciplines and traditions, the study has aimed to highlight the importance of aspects of people's information practices that have been largely unconsidered in existing research in the field, such as affect as a discursive construct and the embodiment of knowledge. Its aim in doing so has been to develop a new approach which allows us a greater understanding of the complexity of people's individual and collective sensemaking.

The author hopes that some of the concepts and issues the study raises may be applied and adapted by other information/knowledge researchers and practitioners - that a study of a traditional Western cultural icon may make a contribution to the emergence of a new kind of information research in the $21^{\text {st }}$ century. In a world that increasingly recognises the limitations of western thought's post-Enlightenment privileging of objectivist rationality, information researchers need to adopt a more holistic approach to understanding how people make sense, one which acknowledges its affective as well as its rationalist components. Equally, the time may be ripe for information researchers to look beyond a Cartesian model of knowledge-as-cognition: to consider what the study's participants already know: that knowing can be a matter for bodies, as well as for minds.

\section{References}

Atkins, P. 2001. Information Literacy and the Arts. College and Research Libraries News 62(11), 1086-8.

Barthes, R. 1988. A Barthes reader. New York, Noonday Press. Belkin, N. 1990. The cognitive viewpoint in information science. Journal of Information Science 16, 11-15.

Berry, R. 1977. On directing Shakespeare: interviews with contemporary directors. London: Taylor and Francis.

Brookes, B. 1980. The foundations of information science. Part 1: Philosophical aspects. Journal of Information Science 2: 125-133.

Bulman, JC. 1996. Shakespeare, Theory and Performance. London and New York: Routledge

Cobbledick, S. 1996. The information seeking behaviour of artists: exploratory interviews. Library Quarterly 66(4): 343-372.

Coupland, J., and R. Gwyn. 2003. Discourse, the body, and identity. Basingstoke, Hampshire; New York: Palgrave Macmillan.

Davies, E. 2007. Epistemic Practices of Theatre Production Professionals: an Activity Theory Approach. Doctoral dissertation: University of Western Ontario, Canada.

Davies, E., and PJ. McKenzie. 2004. Preparing for opening night: temporal boundary objects in textually-mediated professional practice. Information Research, 10(1) paper 211. URL - http://informationr.net/ir/10-1/paper211.html [viewed 31 July 2010]

Derrida, J. 1992. Acts of Literature New York: Routledge.

Derrida, J. 1997. Deconstruction in a Nutshell: a Conversation with Jacques Derrida. New York: Fordham University Press.

Dervin, B. 1999. On studying information seeking and use methodologically: The implications of connecting metatheory to method. Information Processing and Management 35: 727-750.

Dervin, B., and M. Frenette. 2001. Sense-Making Methodology: Communicating communicatively with campaign audiences. In Public communication campaigns, $3^{\text {rd }}$ ed., ed. RE. Rice and CK. Atkin, 69-87. Thousand Oaks, CA: Sage.

Dervin, B., and M. Nilan. 1986. Information needs and uses. Annual Review of Information Science and Technology. 21, 3-33.

Dickens, DR., and A. Fontana. 1994. Postmodernism and social inquiry. New York Guilford Press.

Ellis, D. 1993. Modelling the Information-Seeking Patterns of Academic Researchers: a Grounded Theory Approach. Library Quarterly 63(4): 469-86.

Foucault, M. 1972. The Archaeology of Knowledge. London: Tavistock.

Foucault, M. 1977. Discipline and Punish: The Birth of the Prison. London: Allen Lane.

Foucault, M. 1980. Power/Knowledge: Selected Interviews and Other Writings 1972-1977. London: Harvester Press.

Frohmann, B. 1992. The Power of Images: A Discourse Analysis of the Cognitive Viewpoint. Journal of Documentation 48: 365-86.

Glaser, BG., and AL. Strauss. 1967. The discovery of grounded theory: strategies for qualitative research. New York, NY: Aldine Publishing Corporation.

Golder, J. and R. Madelaine. 2001. O Brave New World: Two Centuries of Shakespeare on the Australian Stage. Sydney: Currency Press. 
Julien, H. 1999. Where to from here? Results of an empirical study and user-centred implications for information design. In Exploring the Contexts of Information Behaviour, ed. T. D. Wilson and D. K. Allen, 586-596. London: Taylor Graham.

Krikelas, J. 1983. Information-seeking behavior: patterns and concepts. Drexel Library Quarterly 19: 5-20.

Kulthau, CC. 1993. A Principle of Uncertainty for Information Seeking. Journal of Communication 49(4): 339-355

Nahl, D., and D. Bilal, (ed.) 2007. Information and Emotion: The Emergent Affective Paradigm in Information Behavior Research and Theory. Medford, NJ: Information Today.

Olsson, M. 1999. Discourse: A New Theoretical Framework for Examining Information Behaviour in its Social Context. In Exploring the Contexts of Information Behaviour - Proceedings of the 2nd Information Seeking in Context Conference, ed. TD Wilson and DK Allen, pp. 136-149. London: Taylor Graham.

Olsson, M. 2003. The Construction of the Meaning and Significance of an 'Author' among Information Behaviour Researchers: a Social Constructivist Approach. Doctoral dissertation: University of Technology, Sydney.

Olsson, M. 2005. Meaning and Authority: the Social Construction of an 'author' among Information Behaviour Researchers. Information Research, 10(2) paper 219 available at http://InformationR.net/ir/10-2/paper219.html [viewed 4 July 2010]

Olsson, M. 2007. Power/Knowledge: the Discursive construction of an Author. Library Quarterly 77(2): 219-40.
Olsson, M. 2009. Re-Thinking our Concept of Users. Australian Academic and Research Libraries 40(1): 22-35.

Pilch, M. 1987. Libraries and the amateur theatre. Information and Library Manager 7(3): 56-58.

Rabinow, P. 1984. The Foucault Reader. Harmondsworth, Middlesex: Peregrine Books.

Savolainen, R. 2007. Information Behaviour and Information Practice: Reviewing the 'Umbrella Concepts' of InformationSeeking Studies. Library Quarterly. 77(2), 109-132.

Seidman, IE. 1991. Interviewing as qualitative research: a guide for researchers in education and the social sciences. New York: Teachers College Press.

Talja, S. 1997. Constituting "information" and "user" as research objects: a theory of knowledge formations as an alternative to the information-man theory. In Information Seeking in Context, ed. P Vakkari, R Savolainen and B Dervin, 6780. London: Taylor Graham.

Wilson, TD. 1997. Information Behaviour: an Interdisciplinary Perspective. In Information seeking in context : proceedings of an International Conference on Research in Information Needs, Seeking and Use in Different Contexts, 14-16 August, 1996, Tampere, Finland, ed. P Vakkari, R Savolainen

Wilson, TD. 2000. Human information behaviour. Informing Science 3(1): 49-55.

Article submitted 9 October 2010; final version received 14 February 2010; accepted 16 February 2010. 